\title{
Effect of Blended Fertilizer and Lime Application Rates on Grain Yield and Yield Component of Maize (Zea mays L.) in Omo Nada District, Jimma Zone South-western, Ethiopia
}

\author{
Alemayehu Abdeta \\ Oromia Agricultural Research Institute, Bedele Agricultural Research Centre, Bedele, Ethiopia \\ Email address: \\ abdeta.alex35@gmail.com \\ To cite this article: \\ Alemayehu Abdeta. Effect of Blended Fertilizer and Lime Application Rates on Grain Yield and Yield Component of Maize (Zea mays L.) in \\ Omo Nada District, Jimma Zone South-western, Ethiopia. American Journal of Bioscience and Bioengineering. \\ Vol. 9, No. 4, 2021, pp. 98-103. doi: 10.11648/j.bio.20210904.11
}

Received: June 3, 2021; Accepted: July 14, 2021; Published: July 22, 2021

\begin{abstract}
Maize (Zea mays L.) is one of the important food security crops and play significant role in the live hood of most Ethiopians. However, yields are low primarily because of low soil fertility and use of inappropriate fertilizer rates. This study was therefore; conducted to determine optimum rates of blended fertilizer under limed and un limed condition of acid soil on Maize in Omo Nada District, Jimma Zone Southwestern, Ethiopia during 2017 main cropping season. The amount of lime that was applied at each location was calculated on the basis of the exchangeable acidity. The experiment used seven treatments; Control, NPS, NPSB, NPSB plus Recommended rate of Lime, NPSB plus $0.75 *$ recommended rate of Lime, NPSB plus $0.50 *$ recommended rate of Lime and NPSB plus $0.25 *$ recommended rate of lime were laid out in randomized complete block design (RCBD) replicated across seven farmers' fields in each location. Application of lime was dramatically improved soil pH from 4.5 to 5.28 . yield and yield components of Maize were significantly affected by integrated use of blended fertilizer and lime. Accordingly, Plant height, Grain Yield, Biomass Yield, Harvest Index and thousand kernel weight of Maize were obtained with application of NPSB plus recommended rate of Lime. Higher net return 15914 Ethiopia birr /ha with marginal rate of return of $557 \%$ of Maize was obtained with application of NPSB plus Recommended rate of Lime. Thus, integrated use of NPSB plus Recommended Lime is recommended for Maize production in acid soil of Omo Nada district and similar agro ecologies.
\end{abstract}

Keywords: Soil pH, Soil Test, Fertilizer Recommendation, Yield

\section{Introduction}

Maize (Zea mays L.) is one of the most important cereal crops in the world. It ranks third among other cereals after wheat and rice [1]. Maize is the most widely grown among cereal crops in Africa and a staple for around half the inhabitants in the continent. Maize accounts for almost half of the calories and protein consumed in Eastern and Southern Africa, and one fifth in West Africa [2]. The low productivity of maize in Ethiopia is attributing able to many factors: soil degradation, nutrient depletion, lack of improved variety, insufficient technology generation [3].

Specially, soil acidity is one among the major factors limiting maize production and productivity in western Oromia, Ethiopia. Currently, it is estimated that about $40 \%$ of arable lands of Ethiopia are affected by soil acidity [4]. Lime is the major means of ameliorating soil acidy [5] because it has very strong acid neutralizing capacity, which can effectively remove existing acid. Lime is the major means of ameliorating soil acidy [5] because it has very strong acid neutralizing capacity, which can effectively remove existing acid.

Hence, soil fertility maintenance is major concerning Ethiopia. Although here is gradual increasing the total volume of fertilizers used in the country, low and unbalanced application rates per unit area of land mainly focusing on Urea and DAP fertilizers with low efficiency of the fertilizers [6] and limited use of improved seeds [7] have still remained major constraints for small farmers to get the best out of the input.

However, the contribution of lime with blended fertilizer on yield and yield attributes of Maize in Omo Nada district had not been determined. Therefore, the objective is to 
determine the effect of blended fertilizer (NPSB) on yield and yield components of Maize under acidic soil condition of in Southwestern particularly in Omo Nada district.

\section{Materials and Methods}

Field experiment was conducted on maize during 2017 cropping seasons on acid soils in Omo Nada district Jimma zones, in Southwestern Ethiopia. Geographically, the district lies between latitudes of $7^{\circ} 17^{\prime}$ to $7^{\circ} 49^{\prime} \mathrm{N} 37^{\circ} 00^{\prime}$ to $37^{\circ} 28^{\prime} \mathrm{E}$ with altitude of 1650-2200 meters above sea level. The rain fall of the area is bimodal, with unpredictable short rains from March to April and the main season ranging over June to September. The minimum and maximum annual rain fall ranges from 1066 to $1200 \mathrm{~mm}$ with mean annual temperature ranging from 18 to $25^{\circ} \mathrm{C}$. The dominant soils of the area was reported [8] Nitisol sand moderately to strongly acidic. The soil has clay in texture and strongly to moderately acidic in reaction.

\subsection{Site and Farmer's Selection}

The experiment was conducted in Oromia region, Jimma zone Omo Nada District. The intervention Kebles were selected based on maize production potential of the area. Farmer sand Site selection from the district was made both by researcher and DA's based on willingness of the farmers.

\subsection{Treatments and Experimental Setup}

The experiment comprised seven treatments were used; (1) Control, (2) NPS, (3) NPSB, (4) NPSB plus Recommended rate of Lime, (5) NPSB plus $0.75^{*}$ recommended rate of Lime, (6) NPSB plus $0.50 *$ recommended rate of Lime and (7) NPSB plus $0.25 *$ recommended rate of lime were laid out in randomized complete block design (RCBD) replicated across Seven farmers' fields in each location with plot size of $10 \mathrm{mx} 10 \mathrm{~m}\left(100 \mathrm{~m}^{2}\right)$. Composite soil samples were taken from seven site randomly selected farm fields. Maize variety $(\mathrm{BH}$ 661) seed rate of 50,000/ha was used with row spacing of 80 $\mathrm{cm}$ between rows and $50 \mathrm{~cm}$ between plants as per there commended practice for the maize crop. Fertilizer rates of $100 \mathrm{~kg} / \mathrm{ha} \mathrm{NPS,} 100 \mathrm{~kg} / \mathrm{ha}$ NPSB and $100 \mathrm{~kg} / \mathrm{ha}$ urea were applied. Urea applied uniformly on all treatments and half urea applied after 45 days.

Table 1. Treatment setup of the experiment.

\begin{tabular}{lll}
\hline Treatment & Fertilizer (k/ha) & Lime Rates \\
\hline 1 & 0 & 0 \\
2 & $100 \mathrm{NPS}+100 \mathrm{Urea}$ & 0 \\
3 & $100 \mathrm{NPSB}+100 \mathrm{Urea}$ & 0 \\
4 & $100 \mathrm{NPSB}+100$ urea & $\mathrm{RL}$ \\
5 & $100 \mathrm{NPSB}+100$ urea & $0.75 * \mathrm{RL}$ \\
6 & $100 \mathrm{NPSB}+100$ urea & $0.50^{*} \mathrm{RL}$ \\
7 & $100 \mathrm{NPSB}+100$ urea & $0.25 * \mathrm{RL}$ \\
\hline
\end{tabular}

Note; $\mathrm{RL}=$ Recommended Lime

\subsection{Treatments Setup and Field Management}

The field was plowed three times before planting; between the end of March and the first week of May 2017. Lastly, the field was leveled and divided into blocks which were then divided into plots. Blended fertilizer, NPSB (18.1N$\left.36.1 \mathrm{P}_{2} \mathrm{O}_{5}-6.7 \mathrm{~S}-0.71 \mathrm{~B}\right)$ nutrient applied at of $100 \mathrm{~kg} / \mathrm{ha}$ represents balanced nutrition recommended for Maize production in the study area [9].

\subsection{Soil Sampling and Lime Requirement Determination}

Initially one composite soil sample from each site was collected from $0-20 \mathrm{~cm}$ depth before lime application and subjected to analyses of acidity attribute and other soil physic-chemical properties. Lime Requirement (LR) of each site was determined based on exchange able acidity (Ex. Ac). Lime application rates determined based on soil test based depending on $\mathrm{pH}$ less than 5.5. Accordingly, Lime Recommendation rates=Exchangeable Acidity* $1.5 * 10$ Kuntal/ha [10]. Lime treatments was applied once at the beginning of the study by broad casting and mixing with the topsoil (depth 0 to $5 \mathrm{~cm}$ ), before deep incorporation by plough to the depth of $20 \mathrm{~cm}$, one months before planting.

\subsection{Data Collection}

One composite soil sample made from 21 sub samples, were collected from the depth of 0 to $20 \mathrm{~cm}$ using auger before planting. The samples were well mixed manually and air dried, then ground using a pestle and a mortar and allowed to pass through a $2 \mathrm{~mm}$ sieve. For lime recommendation, soil sample from site was collected before lime application and subjected to analyses of acidity attribute. When soil $\mathrm{pH}$ is below 5.5, liming is a common method to increase the soil $\mathrm{pH}$ and reduce acidity. But the amount of lime required to bring certain $\mathrm{pH}$ to optimum range for crop growth depends on some factor as organic matter, clay content and soil $\mathrm{pH}$. Soil sample were analyzed after harvest to evaluate changes in soil as a result of applied treatments. The soil samples were analyzed at Bedele Agricultural Research Center.

Agronomic data collected include plant height, biomass yield, grain yield and straw yields, and thousand grains weight and Harvest Index.

\subsection{Statistical Analysis}

The effect of treatments on soil properties and crop parameters were statistically analyzed using Analysis System (SAS) software [11]. When ANOVA result showed significant difference among treatments for each parameter, least significant difference (LSD) test at $5 \%$ probability level was applied for means separation.

\subsection{Economic Analysis}

Economic analysis was conducted based on the procedure provided by CIMMYT [12]. The analysis was done based on the current price of Maize grain and chemical fertilizers. The benefits were taken in the analysis notably the grain yield from each treatment according to the local market and then converted in to birr per hectare from each treatment 
according to the local market and then converted into birr per hectare. The costs of different rate of fertilizer were calculated for each treatment depending on the amount used and converted to per hectare scale. The other costs (seed and crop husbandry agronomic management costs that do not vary among the treatment are not included in this cost analysis. The costs of fertilizers were according to the local market price.

To decide the last recommendation, the value of production was estimated together with calculating the variable production costs of different rate of blended fertilizer. After calculating net benefit by subtracting variable costs from the gross benefits, treatments were ranked from the lowest to the highest variable costs. The dominant analysis was carried out to identify the superior (nondominated) and inferior (dominated) treatments. In this process the superior treatments were selected and the inferior treatments were rejected.

\section{Results and Discussion}

\subsection{Soil Physical and Chemical Properties}

The soil $\mathrm{pH}$ of the experimental site were4.05-5.03 $(\mathrm{pH}$ : $\mathrm{H}_{2} \mathrm{O}$ ). In most cases soils with $\mathrm{pH}$ values less than 5.5 are deficient in $\mathrm{Ca}$ and /or $\mathrm{Mg}$ and also $\mathrm{P}[13,14]$. Total nitrogen percent age of the experimental field was 0.235 and $0.385 \%$ found in low range Landon [15] For soil to be productive, it needs to have organic carbon content in range of $1.8-3.0 \%$ to achieve a good soil structural condition and structural stability [16]. Thus the result agrees with the Author that is 2.134-3.649\%. The result showed that Soil available $\mathrm{P}$ was 1.254-2.652ppm, considered as low [17]. Available P of Nitisols soil is low [18].

Table 2. Selected physical and chemical properties of the experimental soil before sowing of Maize.

\begin{tabular}{lllllll}
\hline Site Number & $\mathbf{p H}$ & Av. P & TN & OC & CEC & RL kun /ha \\
\hline 1 & 4.71 & 2.652 & 0.314 & 3.649 & 14.97 & 5.8 \\
2 & 4.43 & 1.955 & 0.235 & 2.134 & 10.934 & 5.1 \\
3 & 4.27 & 1.939 & 0.268 & 3.635 & 15.339 & 4 \\
4 & 4.41 & 1.907 & 0.236 & 2.563 & 8.16 & 14.2 \\
5 & 4.84 & 2.158 & 0.279 & 3.173 & 9.22 & 5.6 \\
6 & 4.05 & 1.254 & 0.385 & 2.578 & 16.839 & 5.1 \\
7 & 5.03 & 1.943 & 0.378 & 3.04 & 7.483 & 5.6 \\
\hline
\end{tabular}

Note; Av. $\mathrm{P}=$ Available Phosphorus, $\mathrm{TN}=$ Total Nitrogen, $\mathrm{CEC}=$ Cation exchange Capacity, Kun/ha=kuntal per hectare and $\mathrm{RL}=$ Recommended lime.

As showed table 2 the soil $\mathrm{pH}$ of experimental site was low (4.05-5.03) as explained in Recommended lime (4-14.2 $\mathrm{Kuntal} / \mathrm{ha}$ ) as showed (Table 2). Based on soil $\mathrm{pH}$, the soil under the study area $(\mathrm{pH}$ : 4.05-5.03) qualify for extremely acidic to strongly acidic which are $\mathrm{pH}:<4.6,4.6-5.5$ [19]. The result showed that soil $\mathrm{pH}$ affects maize production because soil $\mathrm{pH}$ results less than the maize required proposed as FAO [20] ( $\mathrm{pH}$ 5.5-7). Soil results application of lime and blended fertilizer showed that increased the soil $\mathrm{pH}$ value above 5.0 at all location (Table 3 ).
Table 3. $p H$ values of treatments after harvest lime and blended fertilizer effect Maize.

\begin{tabular}{ll}
\hline Treatment & pH after Harvest \\
\hline control & $4.18^{\mathrm{a}}$ \\
NPS & 4.45 \\
NPSB & 4.6 \\
NPSB+Recommended Lime & 5.67 \\
NPSB $+0.75 *$ Recommended Lime & 5.31 \\
NPSB $+0.5 *$ Recommended Lime & 5.33 \\
NPSB $+0.25 *$ Recommended Rate of Lime & 5.02 \\
\hline
\end{tabular}

As showed table 3 the differences were observed between the treatments. The PH values of treatment plots that received recommended lime plus fertilizer had the highest $\mathrm{pH}$ (5.67). This result is in agreement with [3] who reported the ameliorating effect of lime in reducing soil acidity by increasing soil $\mathrm{pH}$ and reducing activity of aluminum ion in soil solution and reduce exchangeable acidity. However, results of soil collected at harvesting of Maize from un limed treatments indicated decreasing

\subsection{Effect of Blended Fertilizer and Lime on Plant Height}

The result revealed that the effects of blended fertilizer and Lime Application were significant on plant height (Figure 1). The plants in the control pots were shorter than the treated ones on soils from NPSB fertilizer. Maximum of 3.23 mean plant height was recorded at NPSB + Recommended Lime. In contrast, control plot sex habited significantly lower plant height $(1.96 \mathrm{~m})$ compared to all other treatments. The synergy between lime application and plant nutrition was very conspicuous on response to height increments of Maize.

There was continuous and significant increase of plant height in response to the increase in applied lime. The significant Maize plant height increment in response to the increasing lime rates on acidic soils of over the control is because of the lime's ability to neutralize acidic soil toxicity effect and increase soil nutrient availability by enhancing mineralization. Liming might have reduced the detrimental effect of soil acidity on plant growth due to high concentration of $\mathrm{H}+$ and $\mathrm{Al} 3+$ ions in these acid soils in location [21].

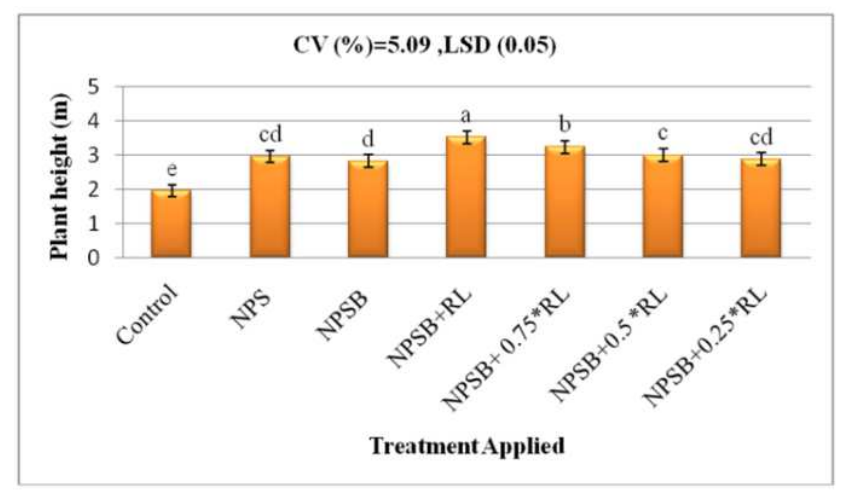

Figure 1. Effect of Lime and blended Fertilizer on plant height $(m)$ of maize.

Bars capped with same letter ( $\mathrm{s}$ ) are not significantly different at $\mathrm{P}=0.05$ according to LSD test. 


\subsection{Effect of Blended Fertilizer and Lime on Grain Yield of Maize}

Application of lime alone did not influence maize production on the study area. NPS and NPSB alone did not affect the yield in the district but their combined application significant affect maize yield. This increased yield might in part due to increased $\mathrm{pH}$ and reduced exchange able aluminum and in part might be due to improved nutrients recovery as a result of lime application.

In present study, the interaction between lime rate and NPSB was significant on the grain yield (Figure 2). The highest mean grain yield of 41.72 kuntal /ha was obtained from NPSB plus recommended rate of Lime. The grain yield obtained was different in all considered lime application. Thus, result revealed that, the increased grain yields obtained on soils from location amended with different lime rates. In other case, the reduction of concentration of exchange able acidity and enhancement of exchangeable bases, CEC and available $\mathrm{P}$. The maize yield increase as a result of increased $\mathrm{pH}$ and reduced exchangeable aluminum and in part due to improved nutrients recovery as a result of lime application [3, 22].

Grain yield is a function of interaction among various yield contributing factors, which are affected differentially by the growing conditions and crop management practices. The final goal of any lime management practices in crop production is to achieve maximum economic yield, which is complex function of individual yield components in response of the practices.

In general, the grain yield/ha was increased with the increase in lime application rates. Results obtained showed that application of blended fertilizer alone or combined with fertilizers significantly increased maize yield over the control. Therefore, instead of applying only fertilizer on acidic soils, it is better to integrated with lime for better production of maize. Application of NPSB+full dose lime significantly increased maize production over other treatment.

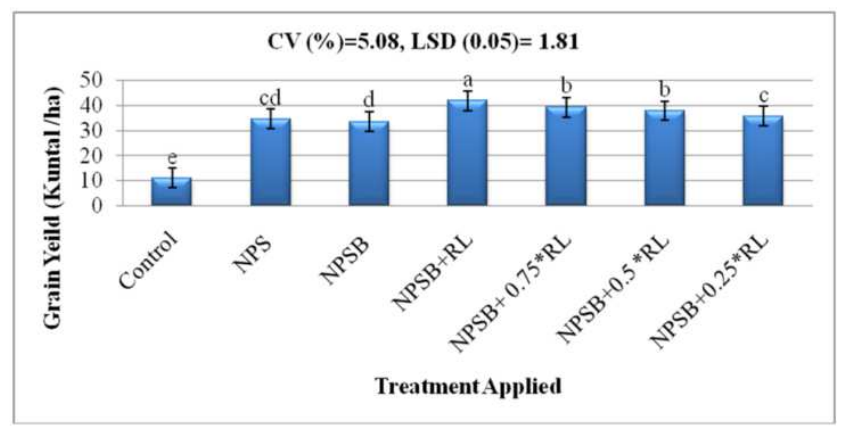

Figure 2. Effect of Lime and blended Fertilizer on Grain Yield (kuntal /ha) of maize.

Bars capped with same letter (s) are not significantly differentiate $\mathrm{P}$ $=0.05$ accordingtoLSDtest.

\subsection{Effect of Blended Fertilizer and Lime on Biomass Yield of Maize (kuntal /ha)}

The effects of lime rates and blended fertilizer highly significant effects on the Maize biomass yield (Figure 3). The lowest total biomass yield was recorded in the control treatment of soils from all the considered location.

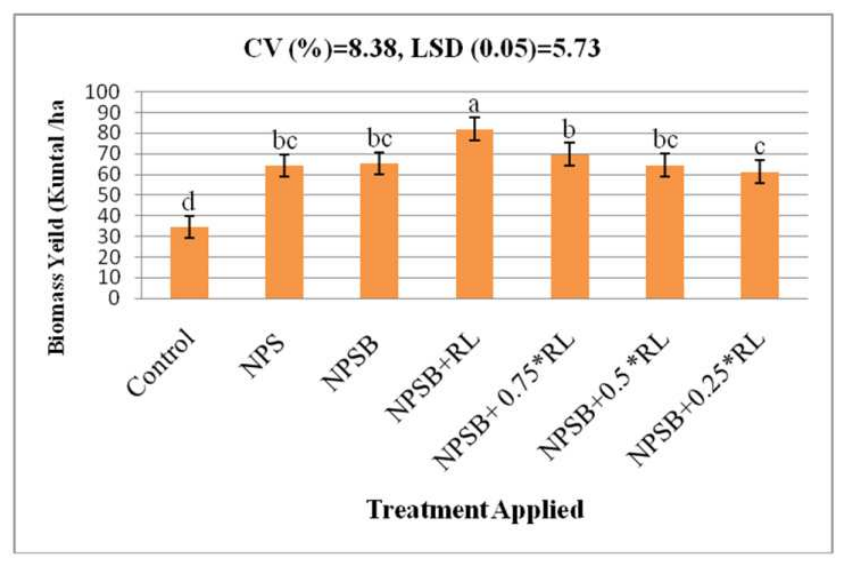

Figure 3. Effect of Lime and blended Fertilizer on Biomass Yield (kuntal/ha) of maize.

Bars capped with same letter ( $\mathrm{s}$ ) are not significantly different $\mathrm{P}=0.05$ according to LSD test.

\subsection{Effect of Blended Fertilizer and Lime on Harvest Index (\%) and Thousand Grain Weight (g) of Maize}

Harvest Index (HI) was highly significantly affected by blended fertilizer and lime (Table 4). An increasing trend of harvest index was observed in response to application of higher rates of NPSB and lime. The highest HI (58.57\%) was obtained with application of 100 NPSB $\mathrm{kg} / \mathrm{ha}$ and full recommended of lime, whereas the lowest value $(32.34 \%)$ was recorded for the control plot (Table 4). The increment in harvest index at higher rate of blended fertilizer combined with lime might be attributed to greater photo assimilate production and its ultimate partitioning into grains compared to the straw part, i.e. proportionally higher grain yield than vegetative biomass yield. On the other hand, low harvest index for the control (unfertilized) treatment might be associated with deficiency of nutrients and there in accessibility for the crop to use. The findings are in line with the data reported by Shiferaw and Anteneh, [22] found that application of lime and all combinations of fertilizers, either alone or combined, significantly increased barley yield over untreated (control).

Result showed that the synergistic effect of applied lime with blended fertilizer nutrient sources highly influenced thousand seed weight of Maize (Table 4). The highest thousand seed weight was recorded with T4; Full recommended lime+ NPSB $(771.43 \mathrm{~g})$ and $\mathrm{T} 5 ; 0.75^{*}$ recommended lime+ NPSB $(771.22 \mathrm{~g})$ over control plots $(442.86 \mathrm{~g})$ which is attributed to better availability of nutrients and grain filling. The lowest thousand seed weight in control plots could be due to shriveled seeds that have small size which contributed to the less grain weight. 
Table 4. Effect of Lime and blended Fertilizer on Harvest Index (\%) Thousand grain weight (gm) of maize.

\begin{tabular}{lll}
\hline Treatment & Harvest Index (\%) & Thousand Kernel Weight $(g)$ \\
\hline Control & $32.34^{\text {bac }}$ & $442.86^{\mathrm{d}}$ \\
NPS & $53.83^{\mathrm{b}}$ & $664.29^{\mathrm{b}}$ \\
NPSB & $52.15^{\mathrm{b}}$ & $664.29^{\mathrm{b}}$ \\
NPSB + RL & $58.57^{\mathrm{a}}$ & $771.43^{\mathrm{a}}$ \\
NPSB $+0.75 * \mathrm{RL}$ & $58.23^{\mathrm{a}}$ & $771.43^{\mathrm{a}}$ \\
$\mathrm{NPSB}+0.5 * \mathrm{RL}$ & $56.27^{\mathrm{a}}$ & $607.16^{\mathrm{c}}$ \\
NPSB $+0.25 * \mathrm{RL}$ & $50.91^{\mathrm{b}}$ & $607.16^{\mathrm{c}}$ \\
LSD & 4.71 & 33.85 \\
CV & 8.39 & 4.46 \\
\hline
\end{tabular}

Note;-RL; Recommended lime

Means followed by the same letter (s) are not significantly different at 5\% $\mathrm{P}$ level; NPSB=Nitrogen, Phosphorus, Sulfur and Boron blended fertilizer, CV (\%) Coefficient of variation; LSD $(0.05=$ Least Significant Difference at $5 \%$ Plevel.

\subsection{Economic Feasibility of Lime Integrated and Blended Fertilizer on Production of Maize}

The results of partial budget analysis data are shown in (Table 5.) Accordingly, the highest net benefit 15160.75 Ethiopia birr /ha with Marginal rates of $556 \%$ was obtained from NPSB $+100 \%$ Recommended lime treatment followed NPSB $+75 \%$ Recommended lime treatment 14149.75 Ethiopia birr/ha with marginal rates of return of $4.19 \%$. This recommendation is also supported by CIMMYT [13] which stated that farmers should be willing to change from one treatment to another if the marginal rate of return of that change is greater than the minimum acceptable rate of return.

Table 5. Economic analysis of integrated use of lime and blended fertilizer.

\begin{tabular}{|c|c|c|c|c|c|c|c|}
\hline \multirow{2}{*}{ Partial budget } & \multicolumn{7}{|c|}{ Treatment } \\
\hline & control & NPS & NPSB & NPSB+100RL & NPSB+0.75RL & NPSB+0.50RL & NPSB+0.25RL \\
\hline Average yield (Ku/ha) & 11 & 35 & 33 & 42 & 39 & 38 & 36 \\
\hline Adjusted yield (Ku/ha) & 10 & 31 & 30 & 38 & 35 & 34 & 32 \\
\hline GB (Birr/ha) & 4941 & 15530 & 15062 & 18774 & 17613 & 17010 & 16029 \\
\hline Urea cost $(\mathrm{Birr} / 100 \mathrm{~kg}$ & 0 & 1080 & 1080 & 1080 & 1080 & 1080 & 1080 \\
\hline NPS cost (Birr/100kg) & 0 & 1350 & 0 & 0 & 0 & 0 & 0 \\
\hline NPSB Cost (Birr/100kg) & 0 & 0 & 1380 & 1380 & 1380 & 1380 & 1380 \\
\hline Labour (100birr/day) & 0 & 0 & 0 & 400 & 300 & 200 & 100 \\
\hline TVC (Birr/ha) & 0 & 2430 & 2460 & 2860 & 2760 & 2660 & 2560 \\
\hline Net benefit & 4941 & 13100 & 12602 & 15914 & 14853 & 14350 & 13469 \\
\hline MRR\% & - & - & $\mathrm{D}$ & 556 & $\mathrm{D}$ & $\mathrm{D}$ & $\mathrm{D}$ \\
\hline
\end{tabular}

Note: RL: Recommended lime, GB: Gross benefit, TVC: Total Variable Cost; NB: MRR\%: marginal rate of return and D: dominated

\section{Conclusion and Recommendations}

Crop development and potential yield depend on different environmental and soil factors. If one of the factors is limiting crop yields declined. Low yield obtained from un-limed but treated with NPS and NPSB mineral fertilizers was common in Omo Nada District. Liming is likely to have increased the $\mathrm{pH}$ levels conducive for availability of most nutrient sand hence its positive effects on maize growth. The effect of lime and blended fertilizer on plant height, Grain Yield, Biomass Yield were significant. The highest plant height, Grain Yield, Biomass Yield were obtained NPSB plus Recommended rate of Lime. Application of 100 recommended lime $+100 / 100 \mathrm{k}$ g/ha NPSB/ urea gave the highest net return 15914 Ethiopia birr with marginal rate return of $556 \%$ which is advisable for farmers to maximize maize grain yield /ha and highest economic return on study area.

\section{Prospects}

Although the effects of blended fertilizer and lime application on Maize has been researched extensively, various aspects remain that need to be investigated. Major gaps in our knowledge of the combined impact of blended fertilizer and lime application still exist. Thus, future research endeavor should focus on:

1) The impact of combined blended fertilizer and lime application based on their properties.

2) Knowledge is also lacking about the application lime needed for amendment.

\section{Competing Interests}

The authors declare that they have no competing interests.

\section{Acknowledgements}

The author thanks Jimma CASCAPE Project for the financial support provided to conduct the experiment. Also the authors gave great full thanks to Professor Gezehagn Barech Jimma University CASCAPE Project Coordinator for his advice. I also would like acknowledge Bedele Agricultural Research Center for their cooperation during field work and soil laboratory analysis.

\section{References}

[1] Food and Agriculture Organization Corporate Statistical Database (FAOSTAT). 2017. Statistical databases and datasets of the Food and Agriculture Organization of the United Nations.

[2] Macauley, H., 2015. Cereal crops: rice, maize, millet, sorghum, and wheat: background paper. Conference on 'Feeding Africa' Dakar, Senegal, 21-23 October 2015. 
[3] Achalu Chimdi, Heluf Gebrekidan, Kibebew Kibret and Abi Tadesse. 2012. Effects of Liming on Acidity-Related Chemical Properties of Soils of Different Land Use Systems in Western Oromia, Ethiopia. World Journal of Agricultural Sciences 8 (6): 560-567.

[4] Taye B (2007) : An over view of acid soils their management in Ethiopia paper presented in the third International Work shop on wate rmanagement (Wterman) project, September, 1921, 2007, Haromaya, Ethiopia.

[5] Anetor and Ezekiel Akinkunmi Akinrinde (2007), "Lime effectiveness of some fertilizers in a tropical acid alfisol", University of Ibadan, Ibadan, Nigeria.

[6] Getachew, A and Chilot, Y. 2009. Integrated Nutrient Management in Faba Bean and Wheat on Nitisols of central Ethiopian Highlands. Research Report No. 72. Ethiopian Inst. of Agric. Res. Addis Ababa, Ethiopia, pp. 24.

[7] Dercon, S., Gilligan, D. O., Hoddinott, J. and Woldehanna, T., 2009. The impact of agricultural extension and roads on poverty and consumption growth in fifteen Ethiopian villages. American Journal of Agricultural Economics, 91: 1007-1021

[8] Eyasu Elias. 2016. Soils of Ethiopian highlands, Geomorphology and properties.

[9] EthioSIS (Ethiopian Soil Information System), "Soil fertility status and fertilizer recommendation in, Ethiopia. July 2014.

[10] Adane Buni., 2014. Effects of liming acidic soils on improving soil properties and yield of haricot bean. Journal of Environmental \& Analytical Toxicology, 5: 1-4.

[11] SAS Institute, Inc. 2012. The SAS System for Windows. Release 9.3; SAS Institute, Inc. Cary, NC, USA

[12] CIMMYT (International maize and wheat improvement Center) (1998): From agronomic data to farmers recommendations. Economics training manual. Completely revised edition. D. F. Mexico lately revised edition. D. F. Mexico.
[13] Marschner, H. (1995). Mineral nutrition of higher plants, 2nd edition, Academic press, Michigan University.

[14] Getachew, A and Sommer, K. 2000. Optimization of the efficiency of phosphate fertilizers in acidic- ferralitic soils of the humid tropics. Ethiopian J. of Natu. Reso. 2: 63-77.

[15] Landon, JR. (Ed.) 1991. Booker tropical soil manual: A Handbook for soil survey and Agricultural Land Evaluation in the tropics and sub tropics. Longman scientific and Technical, Essex, New York. 47 p.

[16] Charman, P and Rope, M. 2007. Soil Organic Matter. pp. 276285. In Charman P. and Murphy B. (Eds.) Soils, Their Properties and Management. 3rd Edition. Melbourne: Oxford University Press.

[17] Berhanu, D. 1980. The Physical Criterion and Their Rating Proposed for Land Evaluation in the Highland Regions of Ethiopia, Land Uses Planning and Regulatory Department, Ministry of Agriculture, Addis Ababa, Ethiopia.

[18] Mesfin A (1998) Nature and Management of Ethiopian soils. Alemaya University of Agriculture, Ethiopia 272.

[19] FAO (Food and Agriculture Organization), Plant nutrition for food security. A guide for integrated nutrient management. Rome, Italy: FAO (Food and Agriculture Organization), 2008.

[20] FAO (Food and Agriculture Organization of the United Nations), World Reference Base for Soil Resources: A Framework for International Classification, Correlation and Communication, World Soil Resources Reports No. 103, $2^{\text {nd }}$ edition, 2006.

[21] Thomas GW and Hargrove WL (1984). The chemistry of soil acidity. pp. 3-56. In: Adams, F. (ed.). Soil Acidity and Liming. American Society of Agronomy, Inc., Madison, WI, USA

[22] Shiferaw Bokore and Anteneh Fikadu (2014). Lime and NPK Effect On Soil Acidity and Yield of Barely in different Acid Soils of Southern Region, Ethiopia. International Journal of Natural Sciences Research 2 (7): 113-122. 